大学生における父親への幻滅とジェンダー・パーソナリティの関係

\author{
畠山孝男 \\ (東北文教大学人間科学部) \\ キーワード : 父親, 幻滅, ジェンダー・パーソナリティ
}

The relationships between disillusionment with fathers and gender personality in college students

HATAKEYAMA Takao

(Faculty of Human Sciences, Tohoku Bunkyo College)

Key words: father, disillusionment, gender personality

近年，父親に関する研究は蓄積されつつあるが，子どもが 父親をどのように認識し評価しているかに関する研究は少な い（森下，2011）。本研究では，大学生が父親に抱く幻滅感 を調查することによって，子どもの側から見た父親像を問題 とする。我が国の父親像，ひいては家庭内での男性像の一側 面が明らかになると思われる。ジェンダー・パーソナリティと 関係することが予想されるので，それについても検討する。

山添（1981）は，父親像変化の契機（幻滅）について，大 学生に 20 答法で記述を求め, その内容項目をもとに, 8 カテ ゴリー全 30 項目の父親像調査質問紙（「父親への幻滅」質問 紙）を作成した。山添（1995）はそれを用いて性差について 検討している。本研究では, 山添（1981）の質問紙と土肥・ 廣川（2004）の「共同性・作動性尺度（CAS）」を実施して, 幻滅のカテゴリーごとの得点を分析し, ジェンダー・タイプ 及び CAS を構成する 4 尺度との関連について検討する。

\section{方 法}

調査対象者 山形県内にある A 大学の $1 \cdot 2 \cdot 3 \cdot 4$ 年生 251 名 (男性 68 名, 女性 183 名, 18-23 歳)。

調査時期 2014 年 12 月。

質問紙「父親への幻滅」質問紙（山添，1981）（5 件法）, 「共同性・作動性尺度 (CAS)」（土肥・廣川, 2004）（4 件法）。

\section{結果と考察}

幻滅質問紙は，家族関係不適応 (3 項目)，人生観断絶 (4 項目), 権威不在 (4 項目), 性格の不一致 (2 項目), 養育態 度の不適切 (8 項目), 身体的・精神的老化 (2 項目), 社会生 活態度の不一致 (4 項目), 家庭生活態度の不適切 (3 項目) の 8 カテゴリーから構成されている。各カテゴリー得点とし て 1 項目当りの評定值を算出した。CAS は,「肯定的作動性」 「肯定的共同性」「否定的作動性」「否定的共同性」の 4 つの 尺度得点を算出し, さらに肯定的共同性と肯定的作動性の得 点で, ジェンダー・タイプを心理的両性具有型, 女性性優位 型, 男性性優位型, 未分化型に分類した。

\section{幻滅の各カテゴリーの平均得点}

各カテゴリーの平均得点（図 1) で，最も幻滅を感じやす いのは男女とも人生観の断絶で, 次いで男性では養育態度の 不適切, 家族関係不適応, 女性では家庭生活態度の不適切, 養育態度の不適切, 家族関係不適応であった。家庭生活態度 の不適切は女性では 2 番目の高さであり, $t$ 検定で男性との 間に有意差が見られた $(p=.005)$ 。女性にとって気になるカテ ゴリーと言える。最も低いカテゴリーは，男女とも身体的・ 精神的老化で，父親の老化については大学生では受容されて いることが分かる。次いで低い社会生活態度の不一致と性格 の不一致は,「どちらともいえない」のレベルであった。

\section{幻滅の各カテゴリー間の相関}

各カテゴリー間の相関はほとんどが中程度以上であった

(表 1)。幻滅を感じる人はどのカテゴリーでも感じやすく, 感じない人はそうでないことが分かる。身体的・精神的老化

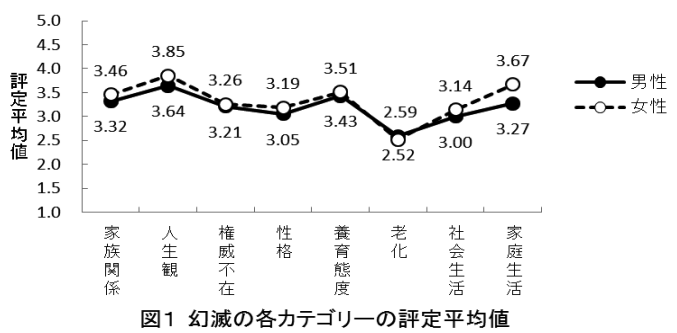

表 1 幻滅の各カテゴリー間の相関

\begin{tabular}{|c|c|c|c|c|c|c|c|c|}
\hline & 家族関係 & 人生観 & 権威不在 & 性 格 & 養育態度 & 老 & 社会生活 & 家庭生活 \\
\hline 家族関係 & & $643^{* *}$ & $671^{*}$ & $549 * *$ & $668^{* *}$ & $340^{* *}$ & $665^{*}$ & $596^{* *}$ \\
\hline 人生観 & $681^{* *}$ & & $569 *$ & $554 *$ & $7777^{*}$ & 078 & $559 *$ & $580 \cdots$ \\
\hline 権威不在 & $660^{*}$ & 678** & & $472^{*}$ & $667^{*}$ & $382^{* *}$ & $670 *$ & $630 *$ \\
\hline 性 格 & $551^{* *}$ & 503** & $505 *$ & & $572 * *$ & $272^{*}$ & $539 *$ & $339_{* *}$ \\
\hline 養育態度 & $696^{*}$ & 794** & $708^{*}$ & $403^{*}$ & & $222^{*}$ & $577^{*}$ & $591 *$ \\
\hline 老 化 & $416^{* *}$ & $405 *$ & $544 *$ & $466^{*}$ & $350 *$ & & $371^{*}$ & $229 * *$ \\
\hline 社会生活 & $654^{* *}$ & 633** & 778** & $574^{*}$ & $630 *$ & $435^{* *}$ & & $513^{* *}$ \\
\hline 家庭生活 & $454^{*}$ & $539 * *$ & $549^{* *}$ & $325 *$ & $618^{* *}$ & $246^{\circ}$ & $483^{* *}$ & \\
\hline
\end{tabular}

は他のカテゴリーとの相関が男女とも高くないが，女性にお いて特に低かった。

\section{ジェンダー・タイプと幻滅の関係}

4タイプにおける各幻滅カテゴリーの平均得点について，1 元配置分散分析を行った。有意差が見られたカテゴリーはな かったが, 有意傾向ないしはそれに近いカテゴリーに着目す ると, 人生観断絶については未分化型の男女とも（男性 $M=4.01$, 女性 $M=4.05)$, 家庭生活態度の不適切では女性性優 位型の男性が $(M=3.80)$, 性格の不一致と養育態度の不適切 では女性性優位型の女性が $(M=3.39 ; M=3.72)$, 幻滅感が大 きいことが示唆された。

各ジェンダー・タイプ内で性差の $t$ 検定を行った。未分化型 と男性性優位型では, 家庭生活態度の不適切について女性の 方が幻滅が大きかった $(p=.003 ; p=.055)$ 。同じ型でも家庭生 活態度に関しては，性別で意識が違うことが注目される。

\section{作動性・共同性と幻滅の関係}

係数は小さいが，肯定的作動性は男女とも，どの幻滅力テ ゴリーとも（男性は家庭生活態度を除き）負の相関を示した

（男性 $r=-.073--.280$, 女性 $r=-.026--.201$ )。作動性が肯定的 に働くと幻滅感が少ないことがわかる。また男性で，肯定的 共同性は幻滅感と負の相関を（家庭生活態度を除き $r=-.148$ - -.391), 否定的共同性は正の相関を示した $(r=.200-.341)$ 。 男性においては共同性が父親との関係の鍵のようである。

\section{引用文献}

土肥伊都子 - 廣川空美 (2004). 心理学研究，75，420-427. 山添正 (1981). 山梨大学教育学部研究報告, 32, 121-128. 山添正 (1995). 神戸親和女子大学論叢, 28, 173-186.

[付記 $] 2014$ 年度東北文教大学人間科学部4年生難波いずみさ んの協力を得た。 